Journal of Biotechnology and Strategic Health Research

Case Report / Olgu Sunumu

http://dergipark.org.tr/tr/pub/bshr

\title{
Atypical Change of Smell Sense in a COVID-19 Patient: A Case Report
}

\section{COVID-19 Hastasında Atipik Koku Duyusu Değişimi: Olgu Sunumu}

(iD $₫$ Erkut Etçioğlu'1, (D) Hamza Ali Akgüneş², (iD Abdülkadir Aydın², (i) Taşkın Tokat ${ }^{3}$

${ }^{1}$ Osmaneli M.S.Ç. State Hospital, Department of Family Medicine, Bilecik, Turkey

${ }^{2}$ Sakarya Training and Research Hospital, Department of Family Medicine, Sakarya, Turkey

${ }^{3}$ Sakarya Training and Research Hospital, Department of Otolaryngology, Sakarya, Turkey

ORCID ID: Erkut Etçioğlu https://orcid.org/0000-0002-8117-7929, Hamza Ali Akgüneş https://orcid.org/0000-0002-6286-5232

Abdülkadir Aydın https://orcid.org/0000-0003-0663-586X, Taşkın Tokat https://orcid.org/0000-0002-4515-8288

^Sorumlu Yazar / Corresponding Author: Erkut Etçioğlu, e-posta / e-mail: erkutetcioglu@gmail.com

Geliş Tarihi / Received : 14.05.2021 Kabul Tarihi / Accepted: 23-06-2020 Yayın Tarihi / Online Published: 30.08 .2021

Atıf Gösterimi/How to Cite: Etçioğlu E., Akgüneş H.A., Aydın A., Tokat T. COVID-19 Hastasında Atipik Koku Duyusu Değişimi: Olgu

Sunumu, J Biotechnol and Strategic Health Res. 2021;5(1):161-165

Abstract

The frequency of sudden loss of smell is quite high among the COVID-19 symptoms described. On the other hand, striking modifications can result due to viral infection in terms of neuronal renewal and function. Viral infections promote an increase in the turnover of the epithelium cells. A 55-year-old male patient who suffered from anosmia after a nasal trauma he received while doing kung-fu 34 years ago and whose sense of smell changed during COVID-19 is presented.

Keywords Anosmia, COVID-19, Destruction, Regeneration

Özet

COVID-19’a dair tariflenen semptomlar arasında ani koku kaybının görülme sıklğı oldukça yüksektir. Öte yandan, viral enfeksiyonlar nöronal yenilenme ve işlev açısından çarpıcı değişiklikler ortaya çıkarabilir. Viral enfeksiyonlar, epitel hücrelerinin dönüşümünün artışına neden olabildiği gösterilmiştir. 34 yll önce kung fu yaparken geçirdiği burun travması sonrası anosmi gelișen ve COVID-19 sırasında koku alma duyusunda değişim olan 55 yaşında erkek hasta sunuldu.

Anahtar Anosmi, COVID-19, Yenilenme, Yikım 


\section{INTRODUCTION}

Severe Acute Respiratory Syndrome Coronavirus 2 (SARS$\mathrm{CoV}-2$ ) infection progresses with various clinical findings. The most reported symptoms are fever, dry cough, fatigue and muscle pain, with other symptoms such as headache and dyspnea. ${ }^{1}$ It can also cause the loss of smell and taste. ${ }^{2}$ The British Association of Otolaryngology has identified the sudden loss of sense of smell and taste as "significant symptoms" which were found even in the absence of other symptoms of Coronavirus Disease 2019 (COVID-19). In particular, it has been suggested that viral infection of the olfactory epithelium causes a sudden loss of sense of smell and usually loss of smell and loss of taste often occur together. ${ }^{2,3}$

It is still unclear exactly how a loss of smell and taste happens with COVID-19, but there are some theories. One theory is that SARS-CoV-2, as with some other similar viruses; causes a loss of olfactory neurons or infection of surrounding and supporting cells of these nerve cells could lead to damage that impacts the ability to smell. The second theory is that the expression of the Angiotensin-Converting Enzyme-2 (ACE-2) receptors to which SARS-CoV-2 binds is higher in the nasal cavity and cells in the olfactory tissue. ${ }^{4}$

Although it is rarely stated that it may be long-term or permanent; in most cases, the loss of smell and taste due to COVID-19 is temporary. It indicates that the damage occurs in the peripheral olfactory system and that the olfactory epithelium is able to self-regenerate in the course of the weeks following the infection. ${ }^{2}$

On the other hand, striking modifications can result due to viral infection in terms of neuronal renewal and function. Viral infections promote an increase in the turnover of the epithelium cells. ${ }^{5}$

A 55-year-old male patient who suffered from anosmia after a nasal trauma he received while doing kung-fu 34 years ago and whose sense of smell improved during COVID-19 is presented.

\section{CASE REPORT}

A 55-year-old male patient with a known case of anosmia, allergic rhinitis, nasal polyps and chronic sinusitis came with a history of fever and cough for approximately 6 days before admission. He stated that these symptoms are increasing day by day.

He had a history of anosmia after nasal trauma he received while doing kung-fu 34 years ago.

He was under Otolaryngology Department follow-up due to the diagnoses of anosmia, allergic rhinitis, chronic sinusitis and nasal polyps in his medical history, stated that his sense of smell did not improve despite the treatments he received.

He was not taking any drugs for approximately 6 months. Family and social histories were unremarkable. On physical examination, the patient was stable and not in acute distress. His vital signs were normal. A neurological examination was normal.

A nasopharyngeal swab sample was taken from the patient, who was suspected of having COVID-19 infection as a pre-diagnosis. The patient was hospitalized when a real-time positive polymerase chain reaction (RT-PCR) examination of the nasopharyngeal sample was detected. The systemic questioning performed during hospitalization revealed that the patient's sense of smell was normal. The patient described that his smell sense significantly improved with the second day of fever and cough which were COVID-19 symptoms. He described the inability to smell coffee, orange, vanilla and bleach before the symptoms of COVID-19.

No corticosteroid or immunochemotherapy was administered. 
Paranasal sinus computed tomography (CT) imaging was performed for this change in sense of smell. His radiological findings were Figure-1. In this CT imaging; image-a was performed 2 years ago (2019) which demonstrates nasal polyposis, bilaterally hypertrophic concha and sinusitis. Image-b was performed during SARS-CoV-2 infection day 3. This image demonstrates regression of sinusitis and nasal polyps according to image-a.

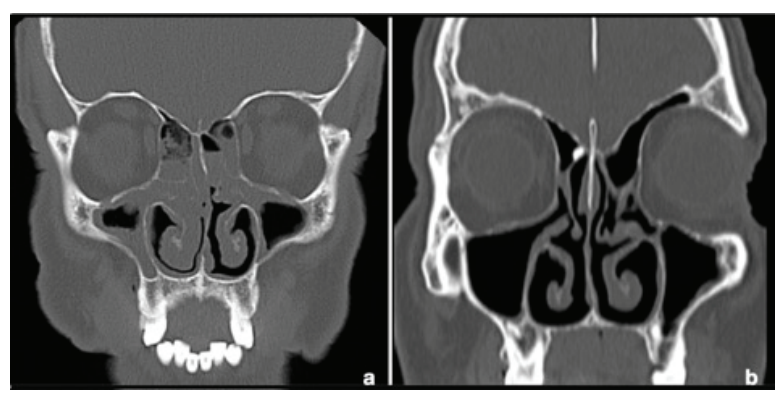

Figure-1: a) Before SARS-CoV-2 infection / b) During SARS-CoV-2 infection

His laboratory findings were normal. He was discharged after his symptoms improved and his general condition remained stable, and he was called for follow-up.

\section{DISCUSSION}

Many symptoms caused by the SARS-CoV-2 virus have been described. These symptoms are caused by the direct damage caused by this virus or cytokine storm-related to viral infection. In this case, we found that the destruction and subsequent production mechanisms triggered by $\mathrm{CO}$ VID-19 or other infections may lead to regeneration and function.

The frequency of sudden loss of smell is quite high among the COVID-19 symptoms described. A worldwide study, which was conducted by the Global Consortium for Chemosensory Research (GCCR) included 4,039 participants from 41 different countries, $89 \%$ of the participants reported a loss of smell. ${ }^{6}$ Nasal obstruction was not associated with smell loss, as commonly observed in other upper respiratory infections. The incidence of anosmia in CO-
VID-19 patients however varies in different studies, ranging from $34 \%$ to $68 \% .^{7}$ Evidence indicates that SARS$\mathrm{CoV}-2$ infection can cause anosmia in a large percentage of the COVID-19 patients. The cellular and molecular mechanisms underlying this effect remain largely unknown.

A remarkable feature of the olfactory epithelium is its capability to generate new olfactory sensory neurons throughout life..$^{8,9}$

The olfactory epithelium is also populated with resident macrophages and dendritic cells, which survey the neuroepithelium and sense pathogens and cell damage. These macrophages express receptors for the chemokine CX3CL1, which is expressed by olfactory sensory neurons located in the intermediate neuronal layer of the epithelium. CX3CL1 modulates macrophage morphology and recruitment. ${ }^{10}$ Macrophages play important roles in the repair of the damaged olfactory epithelium by removing pathogens, phagocytosing dead olfactory sensory neurons, and promoting neurogenesis. ${ }^{11}$

A study showed that intranasal inoculation of the mouse hepatitis virus (MHV; a strain of murine coronavirus $\mathrm{M}-\mathrm{CoV}$ ) that is destructive to the olfactory bulb but not to the olfactory epithelium, promotes an increase in the turnover of the epithelium cells, resulting in a higher proportion of immature olfactory sensory neurons compared to non-infected mice. This study shows that direct viral lesion to the olfactory epithelium is not an obligatory mechanism for post-viral olfactory disorder development; however striking modifications can result due to viral infection in terms of neuronal renewal and function. ${ }^{5}$

On the other hand, Challenor et al. described a SARS$\mathrm{CoV}$-2-induced remission of Hodgkin lymphoma case. In this case report, the hypothesis was SARS-CoV-2 infection triggered an antitumor immune response and this includes cross-reactivity of pathogen-specific $\mathrm{T}$ cells with tumor antigens and natural killer cell activation by inflammatory cytokines produced in response to infection. ${ }^{12}$ 
J Biotechnol and Strategic Health Res. 2021;5(2):161-165

In our case; the reason why the patient could not smell may be due to the presence of nasal polyps, allergic rhinitis, or after nasal trauma. Along with the symptoms of COVID-19, the improvement in the sense of smell may have been caused by the regeneration of olfactory sensory neurons triggered after viral damage. On the other hand, the improvement in the sense of smell may have occurred with the regression of allergic rhinitis, chronic sinusitis and nasal polyps.

Informed consent was taken from the patient.

\section{Financial Support and Interest Relationship}

There is no person/organization that financially supports the work and the authors have no interest-based relationship. 
J Biotechnol and Strategic Health Res. 2021;5(2):161-165

\section{References}

1. Sharma A, Tiwari S, Deb MK, Marty JL. Severe acute respiratory syndrome coronavirus-2 (SARS-CoV-2): a global pandemic and treatment strategies. Int J Antimicrob Agents; 2020; 56: 106054.

2. Glezer I, Bruni-Cardoso A, Schechtman D, Malnic B. Viral infection and smell loss: The case of COVID-19. J Neurochem 2020; doi:10.1111/jnc.15197.

3. ENT UK at The Royal College of Surgeons of England. Loss of sense of smell as marker of COVID-19 infection. Available at: https://www.entuk.org/sites/ default/files/files/ Loss $\% 20$ of $\% 20$ sense $\% 20$ of $\% 20$ smell\%20as $\% 20$ marker\%20of $\% 20$ COVID.pdf. Accessed February 26, 2021.

4. Butowt R, von Bartheld CS. Anosmia in COVID-19: Underlying Mechanisms and Assessment of an Olfactory Route to Brain Infection. Neuroscientist 2020; 1073858420956905 .

5. Schwob JE, Saha S, Youngentob SL, Jubelt B. Intranasal inoculation with the olfactory bulb line variant of mouse hepatitis virus causes extensive destruction of the olfactory bulb and accelerated turnover of neurons in the olfactory epithelium of mice. Chem Senses 2001;26; 937-952.

6. Parma V, Ohla K, Veldhuizen MG, Niv MY, Kelly CE, Bakke AJ, et al. More Than Smell-COVID-19 Is Associated with Severe Impairment of Smell, Taste, and Chemesthesis. Chem Senses 2020; 45 609-622.
7. Meng X, Deng Y, Dai Z, Meng Z. COVID-19 and anosmia: A review based on up-todate knowledge. Am J Otolaryngol 2020; 41: 102581.

8. Schwob JE, Jang W, Holbrook EH, Lin B, Herrick DB, Peterson JN, et al. Stem and progenitor cells of the mammalian olfactory epithelium: Taking poietic license. J Comp Neurol 2017; 525: 1034-1054.

9. Fletcher RB, Das D, Gadye L, Street KN, Baudhuin A, Wagner A, et al. Deconstructing Olfactory Stem Cell Trajectories at Single-Cell Resolution. Cell Stem Cell 2017;20: 817-830.e8.

10. Ruitenberg MJ, Vukovic J, Blomster L, Hall JM, Jung S, Filgueira L, et al. CX3CL1/ fractalkine regulates branching and migration of monocyte-derived cells in the mouse olfactory epithelium. J Neuroimmunol 2008; 205: 80-85.

11. Borders AS, Getchell ML, Etscheidt JT, van Rooijen N, Cohen DA, Getchell TV. Macrophage depletion in the murine olfactory epithelium leads to increased neuronal death and decreased neurogenesis. J Comp Neurol 2007; 501: 206-218.

12. Challenor S, Tucker D. SARS-CoV-2-induced remission of Hodgkin lymphoma. Br J Haematol 2021; 192: 415 